\title{
APPLICATION OF OBJECTIVE MATRIX (OMAX) METHOD FOR MEASURING PRODUCTIVITY OF PROL TAPE PROCESSING IN UD PURNAMA JATI
}

\author{
Dhanang Eka Putra*, Khanifatul Maula Mursid \\ Study Program of Agroindustrial Management, Agroindustrial Management, Department of \\ Agrobusiness Management, Politeknik Negeri Jember \\ Jalan Mastrip 164, Jember 68124, Indonesia \\ *Corresponding Author, Email: dhanangeka@polije.ac.id, khanifatulmaula2@gmail.com
}

\begin{abstract}
The main motivation of this research is to see the level of productivity in prol tape production division of UD. Purnama Jati. in order to increase the prol tape productivity with the Objective Matrix (OMAX) method. The research also performed by evaluating the worst performance ratio with the Traffic Light System. The result shows that the measurement period in June 2019 with a productivity index value of $118 \%$ being the highest productivity index value. Meanwhile, the lowest productivity occurred in the period of July 2019 with a productivity index of $(-47.89 \%)$. Based on the evaluation results of utilizing the Traffic Light System technique, the ratio at the level of "CRITICAL" was a ratio of 1 that is the ratio of productivity of raw materials. UD. Purnama Jati requires to focus on the variables that cause a decline in productivity and can be improved according to the proposed improvements.
\end{abstract}

Keywords: Diagram Ishikawa, OMAX, Productivity, Prol Tape, Traffic Light System

\section{INTRODUCTION}

Productivity reflects certain things which show/measure company performance by comparing the output obtained from the making process (Output) through production input. Productivity can be used as an indicator in business success. This can be useful in figuring out business success in utilizing any resource in making a product. One of several constraints in improving company (Avianda, Yuniati, and Yuniar, 2014). Therefore, it is expected that productivity of this business will be slightly improved.

UD. Purnama Jati is a food business which specializes on produces signature food from Jember Regency, Indonesia. One of their main products is prol tape. Prol tape is signature food of Jember Regency, with semi-moist texture and made of tape (fermented cassava). However, this business has never performed any analysis on its productivity, especially on prol tape production, and also any factors influencing the productivity of production division. Prol tape is a food product which is made and processed not only for improving nutritional value, but also to obtain functional characteristic according to consumers' organoleptic taste (Lestari and Susanto, 2015). Therefore, a productivity measurement on production division of this business is highly needed so that the expected result of the product can be achieved.

Productivity measurement can be performed by using Objective Matrix (OMAX) method. OMAX method is a partial productivity measurement system developed to monitor company productivity by considering appropriate productivity criteria with the applying division (Nasution, 2006). If there is decreased productivity found in the observed division, Objective Matrix (OMAX) method can identify the causes of that decreased productivity. The aim of this research is to find out productivity level and productivity improvement effort in prol tape production division. After measuring the productivity level by using Objective Matrix (OMAX) method, the next step is analyzing it by using Traffic Light System method to figure out the ratio, whether it is in "Good", "Average", and "Poor" condition. If ratio is identified as "Poor", then an analysis on the improvement effort by using Ishikawa Diagram must be performed. 


\section{METHODOLOGY}

This research was conducted in Prol Tape production division of UD. Purnama Jati, located in Jalan Bungur No. 9 Jember Regency, Indonesia in November to December 2019.

\section{Variable Classification}

Variable is classified to identify any variable used in this research. These are some variable classification of this research:

1. Efficiency Criteria (Ratio 1)

2. Effectiveness Criteria (Ratio 2, Ratio 3 and 4)

3. Quality Criteria (Ratio 5)

\section{Definition of Variable Operation}

It is important to elaborate this part based on the result of determined productivity criteria. Productivity Criteria is used in the calculation where the criteria level will be changed into quantitative form to observe company productivity level (Afifi, Tuningrat, and Satriawan, 2015). These are the measurements of each raw material, labor, work hours, production target and featured product criteria

1. Efficiency is a parameter which indicates the importance of the consistency between the projected input and the input used in the analysis.

Ratio 1 = Productivity of Material/Raw Material

Resulted from the formulation of $=\frac{\sum \text { Product Output }(\mathrm{kg})}{\sum \text { Raw Material }(\mathrm{kg})} \times 100 \%$

2. Effectiveness is a parameter which indicates to what extent the expected goal, both from the amount and time aspect, can be achieved.

Rasio 2 = Productivity of Labor Involved

Resulted from the formula of $=\frac{\sum \text { Product Output }(\mathrm{kg})}{\sum \text { Labor Involved (Person) }}$

Rasio 3 = Productivity of Work Hours Spent

Resulted from the formula of $=\frac{\sum \text { Product Output }(\mathrm{kg})}{\sum \text { Work Hours }}$

Ratio 4 = Percentage of Accomplished Production Target

Resulted from the formula of $=\frac{\sum \text { Product Output }(\mathrm{kg})}{\sum \text { Production Target }(\mathrm{kg})} \times 100 \%$

3. Quality is a measurement that indicates how good the resulted product and the input used in the production process.

Ratio 5 = The Percentage of Excellent Quality Products

Resulted from the formula of $=\frac{\sum \text { Actual amount of excellent quality prol tape }(\mathrm{kg})}{\sum \text { Product Output }(\mathrm{kg})} \times 100 \%$

\section{Data Collecting Procedure}

The data source of this research consists of primary and secondary data. These are the primary and secondary data of this research: 


\section{Primary Data}

The primary data of this research was taken from prol tape production division by performing field observation and interview with expert employee and manager of prol tape production division.

2. Secondary Data

The secondary data was taken from the internal data of the company related to prol tape production division. These are including the data on the amount of:
a. monthly raw material used
b. monthly work hours spent
c. monthly target of prol tape production
d. monthly target of prol tape production
e. actual of monthly excellent quality prol tape
f. monthly prol tape product output

\section{Research Design}

This research used descriptive analysis that aims to solve the problem by depicting and analyzing the business condition, in this case is the productivity of prol tape production division.

\section{Research Stages}

The first stage was conducted by a survey to identify any issues of UD. Purnama Jati that related to productivity. Afterwards, the purpose of the research was formulated while performing literature review and the measurement method was selected. After determining the method used, data collection related to the productivity of prol tape production division was executed. The process was continued by analyzing the data using Objective matrix (OMAX) method, evaluating the productivity by using Traffic Light System, finding out the root of the problem by using Ishikawa Diagram and determining the proposed improvement on the business productivity. The last step was drawing conclusion and giving recommendation to improve the productivity.

\section{Objective Matrix Method}

OMAX is a partial system developed to monitor company productivity in certain department, by using productivity criteria which is in line with the relevant department (Nasution, 2006). OMAX research is started with determining productivity criteria, calculating the ratio calculation, calculating matrix value interpolation, arranging goals, determining ratio level and creating OMAX matrix. The formation and structure of Objective Matrix (OMAX) method is as follows: 

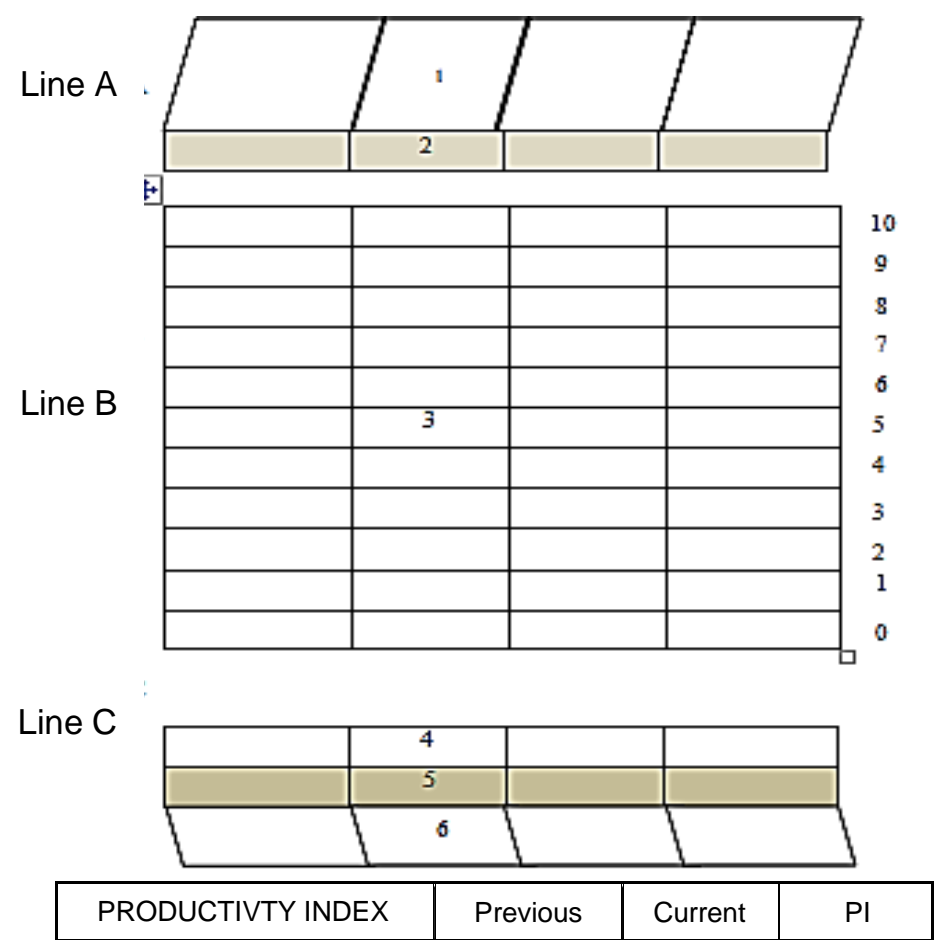

Figure 1. OMAX Model Structure

\section{Ishikawa Diagram Method}

Ishikawa Method is a diagram which shows the cause and effect relation. In this research, Ishikawa Diagram is developed to understand the root of cause leads to the decrease of productivity in prol tape production division.

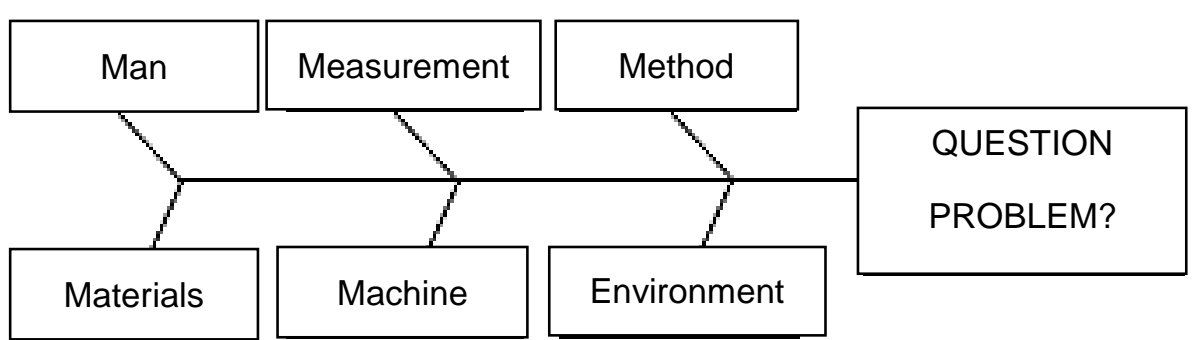

Figure 2. Ishikawa Diagram Formation

\section{RESULTS AND DISCUSSION}

Prol tape is a sweet and semi-moist texture food made of fermented cassava and wheat flour with the ratio of 6:1 (Saji, 2010 in Putri and Hersoelistyorini, 2012). This research refers to (Hamidah, Deoranto, and Astuti, 2013) research, where the object of the research Hamidah used is Sari Roti product, while this research used prol tape product as its research object.

\section{Company Overview}

UD. Purnama Jati is a business unit which specializing in food industry, more specifically on signature souvenir food of Jember Regency. One of their products is semi-moist food called as prol tape. This business was established in 2002 in Patrang District as the central signature souvenir shop of Jember Regency under the name of Purnama Jati. This business offers various foods in several flavor variants. 


\section{Data Determination}

These research data was taken from the business internal data which is correlated to the productivity of production division. These are including:

Table 1. Internal Data of Prol Tape Production in UD. Purnama Jati, Jember Regency

\begin{tabular}{ccccccc}
\hline Period (Month) & $\begin{array}{c}\text { Tape } \\
(\mathbf{K g})\end{array}$ & $\begin{array}{c}\text { Product } \\
\text { Output } \\
\mathbf{( K g )}\end{array}$ & $\begin{array}{c}\text { Work } \\
\text { Hours }\end{array}$ & $\boldsymbol{\Sigma}$ Labor & $\begin{array}{c}\text { Production } \\
\text { Target } \\
\mathbf{( K g )}\end{array}$ & $\begin{array}{c}\boldsymbol{\Sigma} \text { Excellent } \\
\text { Output }\end{array}$ \\
\hline $\begin{array}{c}\text { January } \\
\text { February }\end{array}$ & 2,650 & 5,936 & 200 & 11 & 5,981 & 5,916 \\
$\begin{array}{c}\text { March } \\
\text { April }\end{array}$ & 2,275 & 5,096 & 180 & 11 & 5,115 & 5,074 \\
May & 2,500 & 5,600 & 200 & 11 & 5,622 & 5,594 \\
June & 1,575 & 5,768 & 197 & 11 & 5,801 & 5,760 \\
July & 6,625 & 14,840 & 228 & 20 & 14,930 & 14,800 \\
August & 2,575 & 5,768 & 200 & 11 & 5,778 & 5,761 \\
& 3,025 & 6,776 & 196 & 12 & 6,785 & 6,769 \\
September & 2,450 & 5,488 & 192 & 11 & 5,530 & 5,484 \\
October & 2,675 & 5,992 & 204 & 11 & 6,001 & 5,985 \\
Jumlah & 26,350 & 64,736 & 1,930 & 117 & 65,025 & 64,611 \\
\hline
\end{tabular}

Source: Internal Data of UD. Purnama Jati

\section{Percentage Determination}

After determining productivity criteria, ratio calculation was then performed. These are the productivity percentage for prol tape production division:

Table 2. Productivity Ratio of Prol tape Production Division

\begin{tabular}{cccccc}
$\begin{array}{c}\text { Criteria } \\
\text { Month }\end{array}$ & $\begin{array}{c}\text { Ratio 1 } \\
\text { (\%) }\end{array}$ & $\begin{array}{c}\text { Ratio2 } \\
\text { (Kg/Person) }\end{array}$ & $\begin{array}{c}\text { Ratio 3 } \\
\text { (\%) }\end{array}$ & $\begin{array}{c}\text { Ratio 4 } \\
\text { (\%) }\end{array}$ & $\begin{array}{c}\text { Ratio 5 } \\
\text { (\%) }\end{array}$ \\
\hline $\begin{array}{c}\text { January } \\
\text { February }\end{array}$ & 224 & 539.64 & 29.68 & 99.25 & 99.66 \\
March & 224 & 463.27 & 28.31 & 99.63 & 99.57 \\
April & 224 & 509.09 & 28.00 & 99.61 & 99.89 \\
May & 224 & 524.36 & 29.28 & 99.43 & 99.86 \\
June & 224 & 434.00 & 26.11 & 99.71 & 99.88 \\
July & 224 & 742.00 & 65.09 & 99.40 & 99.73 \\
August & 224 & 524.36 & 28.84 & 99.83 & 99.88 \\
September & 224 & 564.67 & 34.57 & 99.87 & 99.90 \\
October & 224 & 498.91 & 28.58 & 99.24 & 99.93 \\
Average Ratio & 224 & 544.73 & 29.37 & 99.85 & 99.88 \\
The Highest Ratio & 224 & 534.50 & 32.78 & 99.58 & 99.82 \\
The Lowest Ratio & 224 & 742.00 & 65.09 & 99.87 & 99.90 \\
\hline
\end{tabular}




\section{Long-Term Goals Arrangement}

Long-term goals arrangement is closely related to any expected goals that should be accomplished in the future. Therefore, the following calculation is made for each criterion:

Table 3. Long-Term Goals

\begin{tabular}{lccccc}
\hline Description & $\begin{array}{c}\text { Ratio1 } \\
\text { Raw } \\
\text { Material } \\
\text { (\%) }\end{array}$ & $\begin{array}{c}\text { Ratio2 } \\
\text { Labor } \\
\text { Involved } \\
\text { (Kg/Orang) }\end{array}$ & $\begin{array}{c}\text { Rasio3 } \\
\text { Work } \\
\text { Hours } \\
\text { Spent } \\
\text { (Kg/Jam) }\end{array}$ & $\begin{array}{c}\text { Rasio4 } \\
\text { Percentage of } \\
\text { Production } \\
\text { Target } \\
\text { Achievement } \\
(\%)\end{array}$ & $\begin{array}{c}\text { Ratio5 } \\
\text { Percentage } \\
\text { of Excellent } \\
\text { Quality } \\
\text { Product (\%) }\end{array}$ \\
\hline $\begin{array}{l}\text { The Highest } \\
\text { Product Value }\end{array}$ & 225 & 800 & 85.00 & 100 & 100 \\
$\begin{array}{l}\text { The Lowest } \\
\text { Product Value } \\
\begin{array}{l}\text { The Average } \\
\text { of Productivity }\end{array}\end{array}$ & 224 & 434.00 & 26.11 & 99.24 & 99.57 \\
\hline
\end{tabular}

\section{Interval Calculation}

Interval or score calculation was performed using interval scale of each ratio. This method was used up to OMAX matrix formation stage. This part is the described as follows:

Table 4. Interval Calculation of Each Criteria

\begin{tabular}{cccccc}
\hline $\begin{array}{c}\text { Criteria } \\
\text { Level/Score }\end{array}$ & Ratio 1 & Ratio2 & Ratio 3 & Ratio 4 & Ratio 5 \\
\hline 10 & & & & & \\
\hline 9 & 225.00 & 800.00 & 85.00 & 100.00 & 100.00 \\
8 & 224.86 & 762.07 & 77.54 & 99.94 & 99.97 \\
7 & 224.71 & 724.14 & 70.08 & 99.88 & 99.95 \\
6 & 224.57 & 686.22 & 65.62 & 99.82 & 99.92 \\
5 & 224.43 & 648.29 & 55.16 & 99.76 & 99.90 \\
4 & 224.29 & 610.36 & 47.70 & 99.70 & 99.87 \\
3 & 224.14 & 572.43 & 40.24 & 99.64 & 99.84 \\
2 & 224.00 & 534.50 & 32.78 & 99.58 & 99.82 \\
1 & 224.00 & 501.00 & 30.56 & 99.47 & 99.74 \\
& 224.00 & 467.50 & 28.33 & 99.35 & 99.65 \\
\hline
\end{tabular}

\section{Ratio Weight Determination}

In this stage, weight level of each productivity criteria on the total productivity was determined (Nasution, 2006). The ratio weight determination was performed to figure out the ratio which brings the biggest impact on the productivity of prol tape production division of UD. Purnama Jati. This step was executed by brainstorming method by the Production Manager and Business Owner. These are the result of defined weighing activities:

Table 5. Weight of each Productivity Comparison

Productivity of Raw Materia

Productivity of Labor Involved

\begin{tabular}{cc} 
Ratio & Weight (\%) \\
\hline 1 & 30 \\
2 & 25 \\
3 & 15 \\
4 & 20 \\
5 & 10 \\
& $100 \%$
\end{tabular}

Productivity of Work Hours Spent

Persentage of Accomplished Production Target

Percentage of Excellent Quality Product

$100 \%$

Total 


\section{OMAX Calculation}

In calculating OMAX, all company's members contributed in assessing, improving and keeping all the existing condition in production division (Nasution, 2006). OMAX Calculation was performed to facilitate management division in defining any criteria that will be assigned as productivity standards through weight and score of each criterion. (Henni, 2008 in Thaufiq, Astuti, and Deoranto, 2014). Performance criteria were used as productivity measurement in OMAX (Prapti, Iskandar, and Kasutjianingati, 2016). OMAX was done based on the productivity index calculation. These are the productivity level accomplishment in prol tape production division:

Table 6. Accomplishment Level

\begin{tabular}{cccccc}
\hline Period & \multicolumn{5}{c}{ Criteria } \\
\cline { 2 - 6 } & $\begin{array}{c}\text { Raw } \\
\text { Material }\end{array}$ & Labor & Work Hours & $\begin{array}{c}\text { Production } \\
\text { Target }\end{array}$ & $\begin{array}{c}\text { Excellent } \\
\text { Quality } \\
\text { Product }\end{array}$ \\
\hline January & 3 & 3 & 1 & 6 & 1 \\
February & 0 & 0 & 0 & 8 & 8 \\
March & 3 & 2 & 0 & 7 & 5 \\
April & 3 & 2 & 2 & 6 & 4 \\
May & 2 & 0 & 0 & 7 & 5 \\
June & 3 & 8 & 7 & 7 & 1 \\
July & 3 & 2 & 1 & 8 & 5 \\
August & 3 & 3 & 3 & 8 & 5 \\
September & 3 & 1 & 1 & 2 & 7 \\
October & 3 & 3 & 1 & 8 & 5 \\
\hline
\end{tabular}

Based on the OMAX matrix calculation, it is known that there are some causes of the discrepancy on the productivity of each period:

a. In January, ratio 1 and ratio 2 is in level 3 or in normal condition. This situation is caused by the use of pre-defined raw material by UD. Purnama Jati, as well as the normal and appropriate labor productivity as determined. Then, it is followed by ratio 3 and ratio 5 which stay in level 1 . This condition is caused by the productivity value that fails to accomplish the expected goals of UD. Purnama Jati. This also occurred in ratio 5 where the expected goal of excellent quality product is $100 \%$ while in the actual condition; it can only achieve $99.65 \%$. Ratio 4 is in level 6 which means that the ratio is in normal condition since the company's goal achieved is $99.76 \%$ and the expected goal is $100 \%$.

b. In Februari 2019, ratio 1 is in level 3 or in normal condition. Ratio 2 and 3 is in level 0 since the performance achieved is far from the projected goal, where the expected target is 800 $\mathrm{kg} /$ person and $85 \mathrm{~kg} / \mathrm{hour}$ and the performance value of ratio 2 is $463.27 \mathrm{~kg} / \mathrm{person}$ compared to the target of $800 /$ person. Ratio 3 also presented similar condition where the performance value achieved is $28.31 \mathrm{~kg} /$ hour and the expected value target is $85 \mathrm{~kg} /$ hour. Ratio 4 and ratio 5 is in level 8 since its performance value (99.63\% and $99.57 \%)$ is almost reaching out the expected value (100\%). Based on the calculation of the previous period, it is known that PI value decreasing from 3.33 to -22.58 .

c. In March 2019, ratio 1 is in level 3, which means that performance value is in normal condition. This is because the performance value is still at $224 \%$. In ratio 2 and 3 , it is known that the performance value is far from the target, where the actual performance value is $509.09 \mathrm{~kg} /$ person and $28 \mathrm{~kg} / \mathrm{hour}$, while the expected goal is $800 \mathrm{~kg} /$ person and $85 \mathrm{~kg} / \mathrm{hour}$. Ratio 4 and ratio 5 is in average condition where the actual performance value is $99.61 \%$ and $99.89 \%$, while the company's expected goal is $100 \%$ and $100 \%$. Pursuant to the previous period, it can be seen that the productivity value improves from -22.58 to 60.42.

d. In April 2019, ratio 1 is in level 3 which means that the performance value is in normal condition. This is because the performance level does not change and stays in $224 \%$. Ratio 
2 and 3 is in level 2 or in CRITICAL condition since the performance value of both ratio is far from the expected goal, that is $524.36 \mathrm{~kg} /$ person and $29.28 \mathrm{~kg} / \mathrm{hour}$ while the expected goal is $800 \mathrm{~kg} /$ person and $85 \mathrm{~kg} /$ hour. Ratio 4 and 5 is in average condition since the performance value is almost approaching the expected goal, that is $99.67 \%$ and $99.84 \%$. Based on the calculation of previous period, it is concluded that the productivity value is decreasing from 60.42 to -14.29 .

e. In May 2019, ratio 1 is in level 3 which means that the performance value is in normal condition. This is because the performance value does not change and stays at $224 \%$. Ratio 2 and 3 is in level 0 since the ratio performance is far from the expected ratio, where the actual performance value of ratio 2 is $434 \mathrm{~kg} /$ person while the expected performance value is $800 \mathrm{~kg} /$ person. Similar to ratio 2, ratio 3 also fails to achieve the goals, since the actual performance value is $26.11 \mathrm{~kg} /$ hour while the expected value is $85 \mathrm{~kg} / \mathrm{hour}$. On the other hand, ratio 4 and 5 is in the average condition since its performance value is approaching the goal that is $99.82 \%$ and $99.87 \%$. Based on the calculation of the previous period, it is known that the productivity value is decreasing from -14.29 to -24.24 .

f. In June 2019, ratio 1 is in level 3 which means that the performance value is in normal condition. This is because the performance value does not change and stay at $224 \%$. Ratio 2 is in good condition as its performance value is approaching the expected amount, where the actual value is $724 \mathrm{~kg} /$ person and its expected value is $800 \mathrm{~kg} /$ person. Rasio 3 and 4 are in average condition because their actual performance is $65.09 \mathrm{~kg} / \mathrm{hour}$ and $99.82 \%$ while its expected value is $85 \mathrm{~kg} / \mathrm{hour}$ and $100 \%$. Ratio 5 is level 1 since its actual value is far from the projected value, that is $100 \%$. Based on the calculation of the previous period, it can be seen that the productivity value is increasing significantly, that is from -24.24 to 118.

g. In July 2019, ratio 1 is in level 3 which means that the performance value is in normal condition. This is because the performance value does not change and stays at $224 \%$. While ratio 2 and 3 , it is known that the performance value is still far from the expectation, where the actual performance value is $524.36 \mathrm{~kg} /$ person and $28.84 \mathrm{~kg} / \mathrm{hour}$, while the projected performance value is $800 \mathrm{~kg} /$ person and $85 \mathrm{~kg} / \mathrm{hour}$. Ratio 4 is in good condition since the performance value is almost approaching the expected value, where the actual percentage is $99.83 \%$ and the expected percentage is $100 \%$. Ratio 5 is in average condition since its performance value is $99.88 \%$ while the expected value is $100 \%$. Based on the calculation of the previous period, it can be seen that the productivity value is decreasing from 118 to -47.89 .

h. In August 2019, ratio 1, 2 and 3 are in level 3 that indicate normal condition. The performance value of the ratio is complying with the existing standard, yet it still fails in fulfilling the expected target. Here, the performance value of each ratio is $224 \%, 564.7$ $\mathrm{kg} /$ person and $34.57 \mathrm{~kg} / \mathrm{hour}$ while the expected value of each ratio is $225 \%, 800 \mathrm{~kg} / \mathrm{person}$ and $85 \mathrm{~kg} / \mathrm{hour}$. Ratio 4 is in good condition since its performance value is approaching the expected target that is $99.87 \%$ from $100 \%$. Ratio 5 is in average condition as its performance value is $99.87 \%$ while the expected value is $100 \%$. Based on the calculation of the previous period, it can be seen that the productivity value is increasing from -47.89 to 47.89 .

i. In September 2019, ratio 1 is in level 3 which means that the performance value is in normal condition. This is because the performance value does not change and stay at $224 \%$. Ratio 2 and 3 are in level 1 or entering CRITICAL condition since its performance value still fails to meet the defined target. At this point, the actual performance value of each ratio is 498.81 $\mathrm{kg} /$ person and $28.58 \mathrm{~kg} / \mathrm{hour}$ while the expected target for each ratio is $225 \%$, $800 \mathrm{~kg} /$ person and $85 \mathrm{~kg} /$ hour. Ratio 4 is in level 2 since its performance value is still far from the expected point. The actual performance value of ratio 4 is $99.24 \%$ while the expected value is $100 \%$. Ratio 5 is in average condition as its actual performance value is $99.93 \%$ while its expected performance value is $100 \%$. Based on the calculation of the previous period, the productivity value is decreasing from 47.89 to -42.86 .

j. In October 2019, ratio 1 and 2 is in level 3 which indicate normal condition. The performance value of ratio 1 and 2 is complying with the existing standard, yet it still fails in 
fulfilling the expected target. Here, the actual performance value of each ratio is $224 \%$ and $554.73 \mathrm{~kg} /$ person, while the expected value of each ratio is $225 \%$ and $800 \mathrm{~kg} /$ person. Ratio 3 is in level 1 or entering CRITICAL condition since the performance value is still under the expected value. Here, the actual performance value of ratio 3 is $29.37 \mathrm{~kg} / \mathrm{hour}$ while the projected value of each ratio is $85 \mathrm{~kg} /$ hour. Ratio 4 is in good condition since its performance value is approaching its expected goals, that is $99.85 \%$ of $100 \%$. Ratio 5 is in average condition as its performance value is $99.88 \%$ while the target for ratio 5 is $100 \%$. Based on the calculation of the previous period, it can be concluded that the productivity value is increasing significantly from -42.86 to 62.50 .

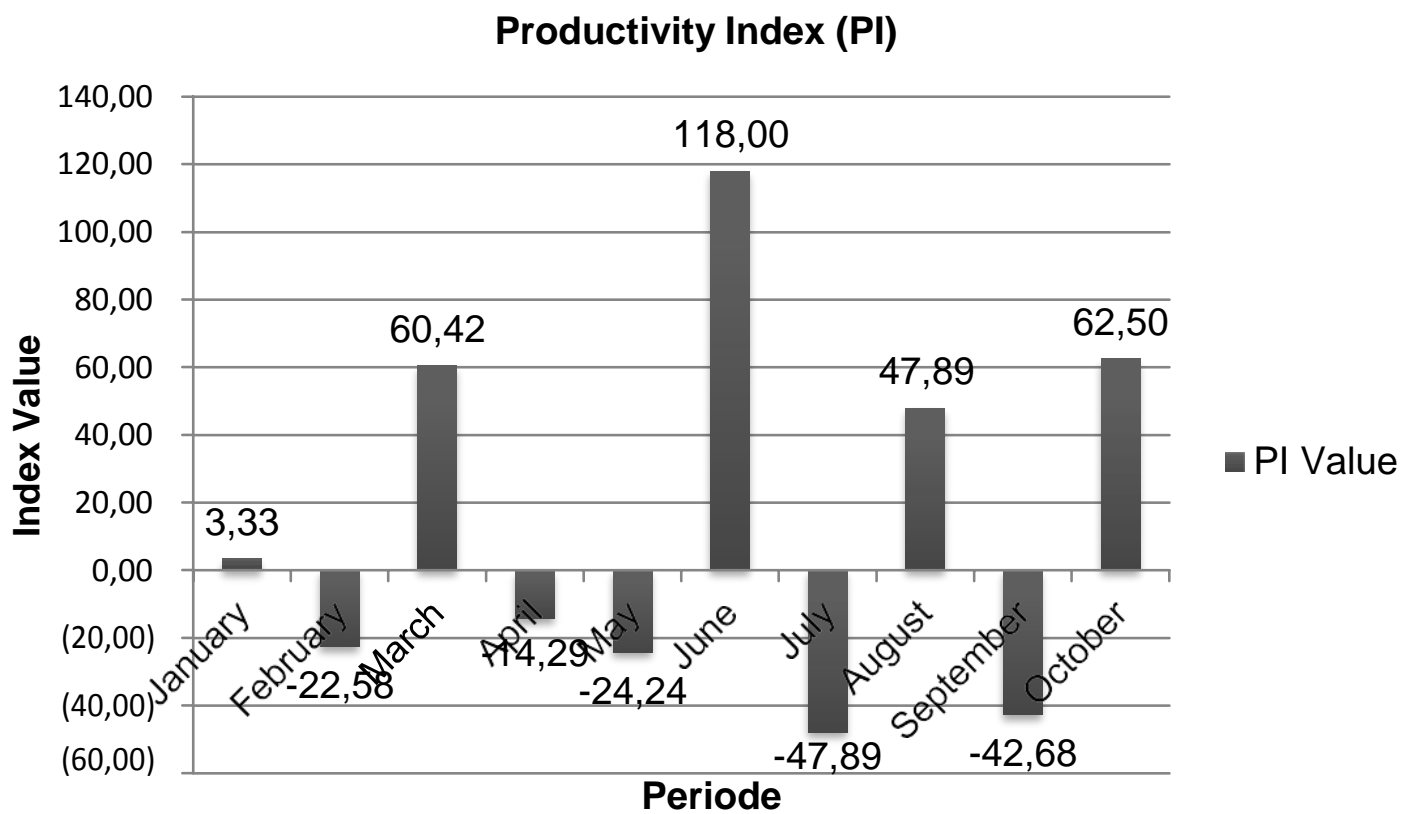

Figure 3. Index Chart of Prol Tape Productivity in UD. Purnama Jati

From the above mentioned graphic, it can be noted that productivity is fluctuating. Fluctuating performance value indicates that the achieved productivity level is not good enough, so it needs an improvement (Eeni, 2009 in Thaufiq, Astuti, and Deoranto, 2014). The highest productivity index value is in June; that is $118 \%$. This is because the productivity level of some criteria crosses the average productivity of that month. In July 2019 , the productivity level is decreasing to $-47.89 \%$ and this is the lowest productivity index of prol tape production division in UD. Purnama Jati. For that reason, root cause analysis must be performed so that productivity improvement can be done by using Ishikawa diagram.

\section{Traffic Light System Analysis}

Traffic Light System is utilized in identifying the productivity ratio which decreased significantly in impacting the productivity of prol tape production division of UD. Purnama Jati. From Traffic Light System analysis, the priority order of improvement can be detected as follows: 
Table 7. Priority Order of Improvement Ratio

\begin{tabular}{lcc}
\hline \multicolumn{1}{c}{ Improvement Rank } & & \\
\hline \multicolumn{1}{c}{ Productivity Criteria } & $\begin{array}{c}\text { Weight } \\
(\%)\end{array}$ & Rank \\
\hline Ratio 1 Productivity of Raw Material & 30 & 1 \\
Ratio 3 Productivity of Works Hours Spent & 20 & 2 \\
Ratio 2 Productivity of Labor Involved & 25 & 3 \\
Ratio 5 Percentage of Excellent Quality Product & 10 & 4 \\
Ratio 4 Percentage of Production Target & 20 & 5 \\
\hline
\end{tabular}

From the previous overview, it can be seen that the lowest productivity ratio is the first ratio or the productivity ratio of raw material. From this point, the improvement must focus on ratio 1 since the scoring result or productivity assessment of 10 consecutive period is in "CRITICAL" condition.

\section{Identification of Productivity Problems}

Cause and Effect Diagram is an illustration that shows a cause-effect relationship (Vincent, 1998). According to Bintang (2005), this illustration is used to present any cause of the derivation (effect) because of that causative factors. Cause and Effect Diagram is used to present the cause of productivity derivation and the characteristic of productivity (effect) from those causative factors. This following is the analysis result of cause and effect diagram in prol tape production division:

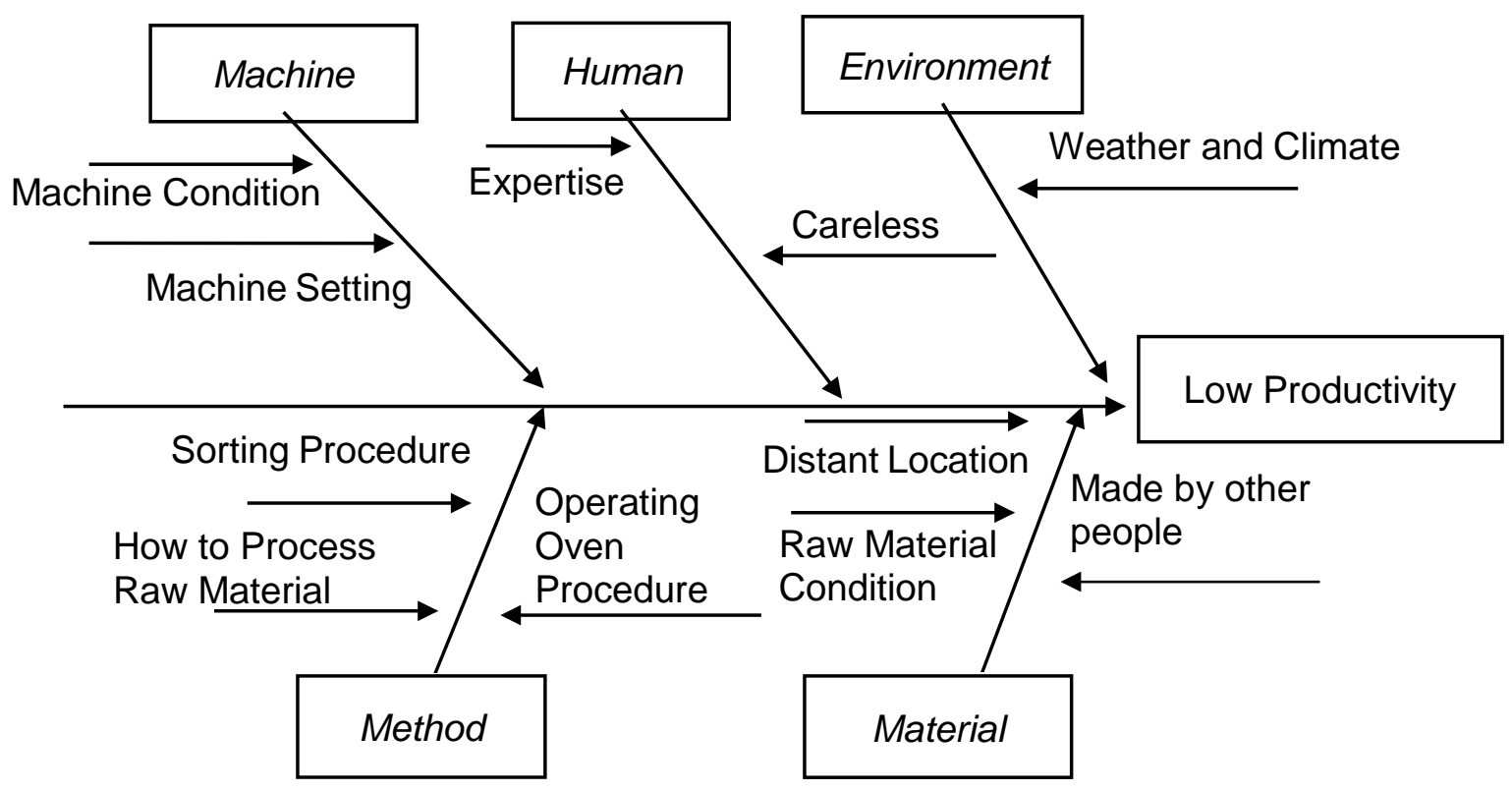

Figure 4. Cause-Effect Diagram on the Cause on Low Productivity Level of Prol Tape Production Division

Based on Figure 4, it reveals the several causes of low productivity level of prol tape production division. Any causes of low raw material are including the condition of raw material, the location where the material is available and the material is not self-made. In Jember regency, the availability of tape (fermented cassava) as raw material of prol tape is limited and unable to cover consumers demand. From human factor, low productivity is caused by low expertise and accuracy. Even so, this condition is also affected by manual sorting method where the employees must have good awareness and expertise. In machine factor, especially on the condition and machine setting, good condition must be ensured to support the production process in the best possible way. From the method factor, some processes such as sorting, operating the oven and raw material processing must be fully maintained since 
method is highly associated with the resulted quality of prol tape. From environment aspect, the effect of certain weather and climate must be fully considered since hot weather or temperature will result in perfect and ripe tape while cool temperature will extend the time for tape ripening and make it less flavorful.

\section{Recommendation on Productivity Improvement}

Productivity improvement can be suggested after considering the causes of low productivity in the business. The improvement is made based on the calculation of average productivity outcomes from January to October 2019. Thus, the improvement ideas can be advised in order to increase productivity of prol tape production division pursuant to the situation and condition, especially for raw material productivity. Overall, the improvement that can be done is by establishing quality standard for the raw material used, performing corrective action related to raw material condition and production estimation to ease raw material availability. The use of high-quality material will also improve production efficiency and effectiveness as well as improve productivity.

\section{CONCLUSION}

The outcome of this research shows that productivity level of UD. Purnama Jati is still fluctuating. This can be drawn from the productivity index value, with the highest productivity index in Juni $2019(118 \%)$ and its productivity value is 545. Meanwhile, the lowest productivity index occurred in July, with the value of $-47.89 \%$ and not much low productivity index, that is 284. From the analysis above, the suggested improvement to increase the productivity is listed in Table 8.

\section{ACKNOWLEDGEMENT}

The authors would like to express their sincere gratitude to Ibu Firdausi as the owner of UD. Purnama Jati, the managers and also the production staffs of UD. Purnama Jati for the assistance in preparing the data related to the productivity of prol tape production.

\section{REFERENCES}

Afifi, A., Tuningrat, I. A. M., \& Satriawan, I. K. (2015). Analisis Produktivitas Produksi Di Perusahaan Kecap Manalagi Denpasar. Jurnal Rekayasa Dan Manajemen Agroindustri, 3(3), 133-142.

Avianda, D., Yuniati, Y., \& Yuniar, Y. (2014). Strategi Peningkatan Produktivitas di Lantai Produksi Menggunakan Metode Objective Matrix. Jurnal Online Institut Teknologi Nasional, 1(4), 202-213.

Bintang, M. (2005). Analisis Faktor-faktor yang Berpengaruh terhadap Performansi Karyawan (Studi Kasus: PKS. PTPN-II Sawit Seberang). Jurnal Sistem Teknik Industri, 6(3), 1314.

Hamidah, N. H., Deoranto, P., \& Astuti, R. (2013). Analisis Produktivitas Mengguakan Metode Objective Matrix (OMAX): Studi Kasus pada Bagian Produsi Sari Roti PT Nippon Indosari Corpindo, Tbk Pasuruan. Jurnal Teknologi Pertanian, 14(3), 215-222.

Lestari, D. P., \& Susanto, W. H. (2015). Pembuatan Getuk Pisang Raja Nangka (Musa Paradisiaca) Terfermentasi dengan Kajian Konsentrasi Ragi Tape Singkong dan Lama Terfermentasi. Jurnal Pangan Dan Agroindustri, 3(1), 23-31.

Nasution, A. H. (2006). Manajemen Industri. Yogyakarta: Penerbit Andi.

Prapti, K. P., Iskandar, R., \& Kasutjianingati, -. (2016). Strategi Peningkatan Kinerja Supply Chain Buah Naga di Kecamatan Bangorejo Kabupaten Banyuwangi Berdasarkan Proses Inti SCOR. Jurnal IImiah Inovasi, 15(3), 94-98. https://doi.org/10.25047/jii.v15i3.19

Putri, S. W. A., \& Hersoelistyorini, W. (2012). Kajian Kadar Protein, Serat, HCN, dan Sifat Organoleptik Prol Tape Singkong dengan Subtitusi Tape Kulit Singkong. Jurnal Pangan Dan Gizi, 3(6), 17-27. 
Thaufiq, M. R. I., Astuti, R., \& Deoranto, P. (2014). Analisis Produktivitas Bagian Pengolahan Susu Pasteurisasi Menggunakan Metode Objective Matrix (OMAX) (Studi Kasus Koperasi SAE Pujon). Thesis. Universitas Brawijaya.

Vincent, G. (1998). Manajemen Produktivitas Total: Strategi Peningkatan Produktivitas Bisnis Global. Jakarta: PT Gramedia Pustaka Utama. 